\title{
ADVANCED PURIFICATION OF INDUSTRIAL AND MIXED WASTEWATER BY COMBINED MEMBRANE FILTRATION AND SONOCHEMICAL TECHNOLOGIES
}

\author{
Enrico Fatarella ${ }^{1}$ \\ Irene Cioni ${ }^{1}$ \\ Cecilia Caretti $^{2}$ \\ Enrico Venturini degli Esposti ${ }^{l}$ \\ Ester Coppini ${ }^{3}$ \\ ${ }^{I}$ Next Technology Tecnotessile - Prato (Italy) \\ ${ }^{2}$ Civil Engeneering Department - University of Florence \\ ${ }^{3}$ GIDA Spa - Prato (Italy)
}

\begin{abstract}
The textile sector plays a critical role in this context, because textile companies are large users of water - typically $0.2-0.5 \mathrm{~m} 3$ are needed to produce $1 \mathrm{~kg}$ of finished product [1] - and they are historically concentrated in districts (e.g. Prato in Italy) located in Southern Member States, such as Italy, Spain and Portugal, which are facing more and more longer periods of drought and therefore are strongly in the need to preserve the availability of water for potable use. The finishing processes (i.e. pre-treatment, dyeing, printing and special finishing) are especially polluting and resource consuming in terms of water, energy and chemicals. Almost the entire of water used in textile production is discharged and, on average, the effluents volume covers $90-95 \%$ of the water used [2].

According to that, a new Ultrafiltration/Sonichemical combined process has been investigated on textile wastewater by evaluating the reduction of the pollution load induced by physical separation and by chemical oxidation promoted by Ultrasound cavitation. The experimental campaign carried out at the Municipal Wastewater treatment Plant in Prato showed that the quality of the treated water reaches the target reported in literature [3] for textile manufacturing sectors. An estimation of the costs of the purified water has been assessed and the combined process seems to be promising for further development.

The authors would like to thank the European Commission to funding this project (contract number LIFE07/IT/000439) within the LIFE+ Environmental Policy and Governance 2007 Programme.
\end{abstract}

\section{KEYWORDS}

textile wastewater; mixed wastewater, Ultrafiltration, Ultrasound 


\section{INTRODUCTION}

Industrial wastewaters contain pollutants recalcitrant to conventional oxidation and biological treatments which must be effectively removed or degraded for water reuse and/or recycle. For this aim the use of advanced oxidation processes (AOPs) is of increasing interest and application. AOPs produce in situ transitory species (mainly hydroxyl radicals) which aid in the degradation process until the target pollutant species are partially or completely converted to more simple compounds. In the recent years, membrane filtration processes have been increasingly applied for the refinement of reclaimed wastewater to be reused because they have the advantages of gaining several positive effects on water quality, saving space and chemicals. Although membrane processes can allow also the separation of low molecular weight and ions to produce permeate colorless and low in total salinity, micro-filtration (MF) and ultra-filtration (UF) are usually used, for refinement of industrial wastewater to be reused, to remove particles, colloids and macromolecules. In the case of reclaimed textile wastewater MF and UF permeate is very low in turbidity and suspended solids, but due to its residual color it cannot be directly reused for some wet textile processes such as dyeing. The combined treatment of membrane filtration and ultrasound treatment seems to be a viable alternative for the refinement of treated effluent to be reused. Within the PURIFAST project, this novel approach, which has not yet been employed on the full industrial scale, will be experienced at pilot scale, in different contexts. In the first part of the pilot plant tests, the combined treatment has been experienced at the Baciacavallo WWTP (managed by GIDA $\mathrm{SpA}$ ) for the refinement of the reclaimed effluent to be reused in wet textile processes. The combination of ultrafiltration and the ultrasound treatment has been compared to alternative tertiary treatments applied by GIDA SpA. At Baciacavallo WWTP (about 750,000 p.e., maximum flow capacity of $6,000 \mathrm{~m}^{3} / \mathrm{h}$ ) almost $70 \%$ of incoming wastewater originates in the textile industry and is characterized by high concentrations of surfactants and dyes. Before to be discharged, the secondary effluent is refined using a coagulation-flocculation treatment and ozonation. A share of the reclaimed wastewater (up to $4 \mathrm{Mm}^{3} \mathrm{y}^{-1}$ ) undergoes further refinement and is reused for wet textile processes (see figure 1 for a layout of the system). At present reclaimed wastewater is refined with the following treatment train: coagulationflocculation, low pressure sand filtration and ozonation. 


\section{MATERIAL AND METHODS}

The effluents of the WWTP at Baciacavallo have been fed into the small scale prototypes according to the configuration that will be described and detailed in the section "Testing design configuration". Two different pilots (a UF pilot provided by Inge and a US device provided by LAVO) have been used for the realisation of the Pilot Scale Tests. A summary of the main characteristics of the realised pilots is reported in the tables below.

UF Pilot (INGE)

\begin{tabular}{|l|l|}
\hline Parameter & Description \\
\hline Membrane configuration & $\begin{array}{l}\text { Capillaries working in dead-end } \\
\text { configuration (inside/outside) }\end{array}$ \\
\hline Number of membrane & $\begin{array}{l}1 \text { membranes: } \\
\text { UF100 }\end{array}$ \\
\hline Pore size of the membrane & $0.02 \mu \mathrm{m}$ \\
\hline Capillary diameter & $1.5 \mathrm{~mm}$ (UF100) \\
\hline Membrane area & $0.2 \mathrm{~m}^{2}$ for each membrane \\
\hline Feed Flow & $101 / \mathrm{h}$ for each membrane \\
\hline Raw water flux & $501 / \mathrm{m}^{2} \mathrm{~h}$ \\
\hline Pre-filter pore size & $300 \mu \mathrm{m}$ \\
\hline
\end{tabular}

Ultrasonic equipment (LAVO)

\begin{tabular}{|l|l|}
\hline Parameter & Description \\
\hline Frequency & $350 \mathrm{kHz}$ \\
\hline Transducer geometry & Cup horn \\
\hline Number of transducer & 24 arranged in three independent groups \\
\hline Power per US group & $1.5 \mathrm{~W} / 1$ (1 group working) \\
& $3.1 \mathrm{~W} / 1$ (2 groups working) \\
& $4.7 \mathrm{~W} / 1(3$ groups working) \\
\hline Acoustic power & 72.5 \\
\hline Radical formation rate & $5.52 \mu \mathrm{mol} / 1$ min \\
\hline
\end{tabular}

The two pilots have been installed according to the following configuration. 


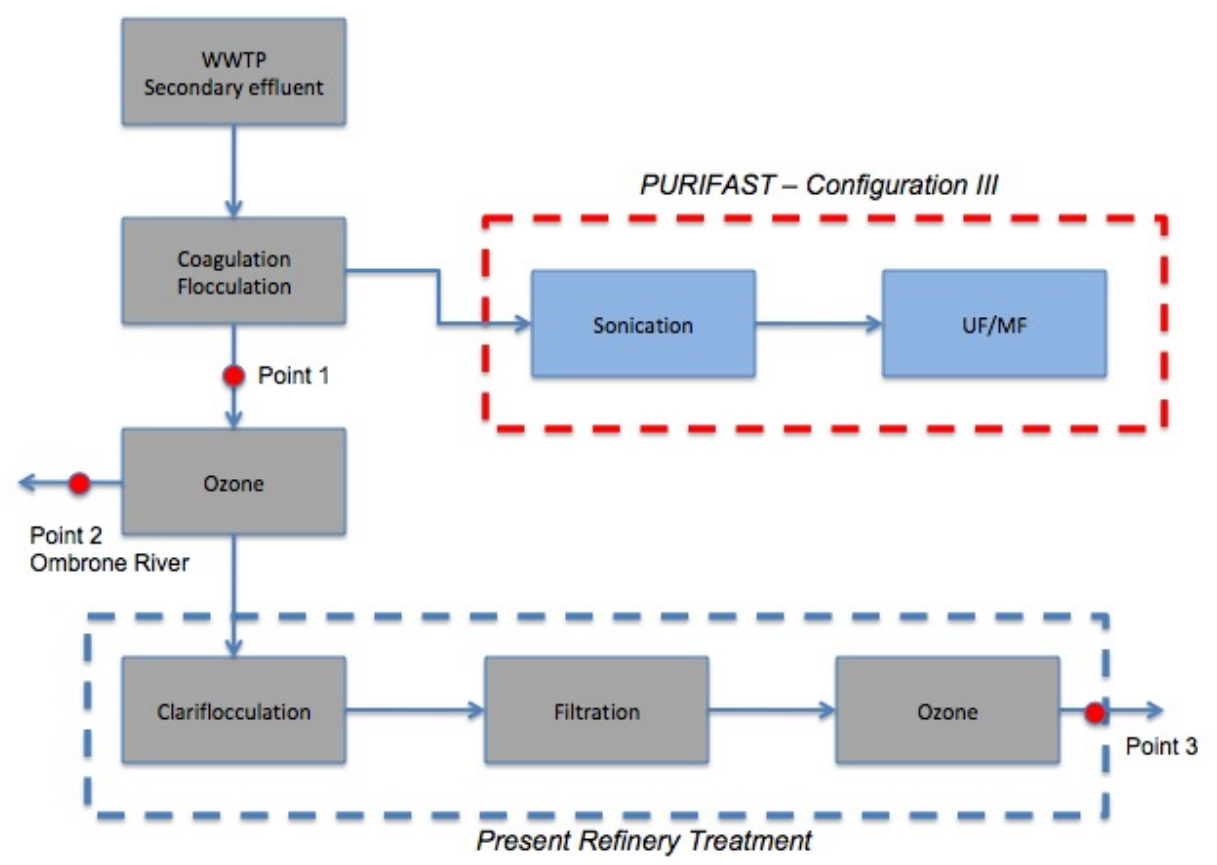

Figure 1 - Configuration tested within PURIFAST project (in blue) compared with the conventional treatment used at GIDA (in grey). The conventional refinery treatment applied at GIDA has been highlighted.

The characterisation of the filtration system has been done by continuously monitoring the following parameters: Transmembrane Pressure (TMP); Permeability (Lp) and Fluxes (F). In fact, TMP is defined as the difference in pressure between the raw water side (retentate) of the membrane and the filtrated water side (permeate) of the membrane. The pressure is the driving force for the membrane filtration. Since we are working at constant flow, an increase in the transmembrane means that a deposit cake is present on the surface of the membrane. The hydraulic permeability (Lp) is a parameter that reflects the relationship between the Flux and the TMP. A decrease in the permeability means that some fouling on the membrane is occurring. In order to define the best filtration conditions (production time, backwashes frequency, chemical cleaning frequencies) during the experimental campaigns, sustainable operating conditions have been researched. Sustainable operating conditions mean that for a fixed flux, the TMP increase is not too fast and can be stabilized over the time thanks to frequent hydraulic backwash and chemical cleans. 
Chemical and physical characterisation of the effluent has been done by investigating the parameters selected for textile reuse on a daily basis (table 1).

Table 1 - Parameter investigated at pilot scale.

\begin{tabular}{|c|c|c|}
\hline Parameter & Unit & Standard Tests \\
\hline $\mathrm{pH}$ & - & $\mathrm{pH}$ meter \\
\hline Conductivity & $\mu \mathrm{S} / \mathrm{cm}$ & Conductimeter \\
\hline Turbidity & NTU & IRSA 2120 \\
\hline Total Suspended Solids (TSS) & $\mathrm{mg} / \mathrm{L}$ & IRSA 2050 \\
\hline Hardness & $\mathrm{mg} / \mathrm{L}$ & $\begin{array}{l}\text { Merk, Dr. Lange - Tritation with } \\
\text { EDTA }\end{array}$ \\
\hline Colour & $\mathrm{A} / \mathrm{nm}$ & $\begin{array}{l}\text { UV/Vis spectrophotometer range } \\
400-700 \mathrm{~nm}\end{array}$ \\
\hline Silica $\left(\mathrm{SiO}_{2}\right)$ & $\mathrm{mg} / \mathrm{L}$ & Dr. Lange - DIN 38405-D21 \\
\hline Chlorides & $\mathrm{mg} / \mathrm{L}$ & Dr. Lange \\
\hline Sulphates & $\mathrm{mg} / \mathrm{L}$ & $\begin{array}{l}\text { Merk, Dr. Lange - EPA } 375.4- \\
\mathrm{BaCl}_{2} \text { method }\end{array}$ \\
\hline $\begin{array}{l}\text { Chemical Oxygen Demand } \\
\text { (COD) }\end{array}$ & $\mathrm{mg} / \mathrm{L}\left(\mathrm{O}_{2}\right)$ & $\begin{array}{l}\text { Dr. Lange, Merk - DIN38409 - } \\
\text { ISO6060 }\end{array}$ \\
\hline Total Organic Carbon (TOC) & $\mathrm{mg} / \mathrm{L}\left(\mathrm{CO}_{2}\right)$ & Dr. Lange - DIN30409 H3 \\
\hline $\begin{array}{l}\text { Biochemical Oxygen Demand } \\
\left(\mathrm{BOD}_{5}\right)\end{array}$ & $\mathrm{mg} / \mathrm{L}\left(\mathrm{O}_{2}\right)$ & Respirometric analysis \\
\hline Total Surfactants (TS) & $\mathrm{mg} / \mathrm{L}$ & Computed as MBAS + BiAS \\
\hline Toxicity & $\%$ immobilization & Daphnia Magna - DAPHTOX kit F \\
\hline Silt Density Index (SDI) & - & \\
\hline
\end{tabular}

The Silt Density Index has been measured by filtering the effluent coming from the UF or the combined process by using a Millipore filter (pore size $0.45 \mathrm{~nm}$ ). The duration of the trial is 15 minutes and according to this condition the SDI have been computed according to the following equation:

$$
S D I=\frac{100\left(1-\left(t_{i} / t_{f}\right)\right)}{t}
$$

where $t_{i}=$ time required to filter $500 \mathrm{ml}$ and $t_{f}=t_{i}+$ time required to filter additional $500 \mathrm{ml}$. 


\section{RESULTS AND DISCUSSION}

In the table below (table 2) a summary of the concerning the quality of the wastewater inlet to the pilot and coming from the ozonation processes (these data will be compared with the performances of the Ultrasonic treatment) during the experimental campaign.

Table 2 - Quality of the effluent coming from point 1 and point 2 at Baciacavallo WWTP

\begin{tabular}{|c|c|c|c|c|}
\hline \multirow[t]{2}{*}{ Parameter } & \multirow[t]{2}{*}{ Unit } & Before ozonation & $\begin{array}{c}\text { After } \\
\text { ozonation }\end{array}$ & \multirow{2}{*}{$\begin{array}{c}\text { PURIFAST } \\
\text { Target }\end{array}$} \\
\hline & & Average & Average & \\
\hline $\mathrm{pH}$ & - & 7.4 & 7.3 & $6-8$ \\
\hline Conductivity & $\mu \mathrm{S} / \mathrm{cm}$ & 1686 & 1657 & $\leq 3000$ \\
\hline Turbidity & NTU & 5.5 & 6.8 & $\leq 5$ \\
\hline TSS & $\mathrm{mg} / \mathrm{L}$ & 10.7 & 14.5 & $\leq 5$ \\
\hline Hardness & $\mathrm{mg} / \mathrm{L}$ & N.A. & N.A. & $\leq 50$ \\
\hline Colour & $\mathrm{A} / \mathrm{nm}$ & 16.38 & 8.21 & $\leq 2$ \\
\hline $\mathrm{SiO}_{2}$ & $\mathrm{mg} / \mathrm{L}$ & 6.34 & 6.9 & $\leq 25$ \\
\hline Chlorides & $\mathrm{mg} / \mathrm{L}$ & 460 & 461 & $\leq 500$ \\
\hline Sulphates & $\mathrm{mg} / \mathrm{L}$ & 169 & 155 & $\leq 300$ \\
\hline COD & $\mathrm{mg} / \mathrm{L}\left(\mathrm{O}_{2}\right)$ & 47.4 & 46 & $\leq 35$ \\
\hline $\mathrm{TS}$ & $\mathrm{mg} / \mathrm{L}$ & 0.39 & 0.29 & $\leq 0.5$ \\
\hline Toxicity & $\begin{array}{l}\% \\
\text { immobilization }\end{array}$ & Non toxic & Non toxic & Non toxic \\
\hline SDI & & N.A. & N.A. & 5 \\
\hline
\end{tabular}

\subsection{Test with Ultrasonic equipment provided by LAVO}

In order to reduce the impact of the fouling induced by the high pollution load of the non ozonised wastewater a new configuration have been tested: the performances of the conventional AOP process performed at GIDA (ozone treatment with a dosing of ozone $=19$ $\mathrm{g} / \mathrm{m}^{3}$ ) have been compared with the one achieved by treating the effluent from the clariflocculation with the Ultrasonic treatment. The following results have been obtained (table 3). 
Linnaeus ECO-TECH '10

Kalmar, Sweden, November 22-24, 2010

Table 3 - Results of the chemical and physical characterisation of treated wastewater with US

\begin{tabular}{|c|c|c|c|c|c|c|}
\hline \multirow[b]{2}{*}{ Parameter } & \multirow[b]{2}{*}{ Unit } & \multirow[b]{2}{*}{ Ozonation } & \multicolumn{3}{|c|}{ US (non ozonated water) } & \multirow{2}{*}{$\begin{array}{c}\text { PURIFAST } \\
\text { Target }\end{array}$} \\
\hline & & & $\begin{array}{c}\text { Low } \\
\text { value }\end{array}$ & $\begin{array}{c}\text { Max } \\
\text { Value }\end{array}$ & Average & \\
\hline $\mathrm{pH}$ & - & 7.37 & 7.1 & 7.5 & 7.1 & $6-8$ \\
\hline Conductivity & $\mu \mathrm{S} / \mathrm{cm}$ & 1657 & 1590 & 2380 & 1847 & $\leq 3000$ \\
\hline Turbidity & NTU & 6.8 & 3.6 & 10.0 & 7.8 & $\leq 5$ \\
\hline TSS & $\mathrm{mg} / \mathrm{L}$ & 14.5 & 6.8 & 12.8 & 9.7 & $\leq 5$ \\
\hline Hardness & $\mathrm{mg} / \mathrm{L}$ & 32.6 & 29.8 & 31.8 & 30.2 & $\leq 50$ \\
\hline Colour & $\mathrm{A} / \mathrm{nm}$ & 8.21 & 4.45 & 10.78 & 8.89 & $\leq 2$ \\
\hline $\mathrm{SiO}_{2}$ & $\mathrm{mg} / \mathrm{L}$ & 6.9 & 6.07 & 9.55 & 9.06 & $\leq 25$ \\
\hline Chlorides & $\mathrm{mg} / \mathrm{L}$ & 461 & 322.2 & 390.9 & 340.5 & $\leq 500$ \\
\hline Sulphates & $\mathrm{mg} / \mathrm{L}$ & 155 & 133 & 244 & 201 & $\leq 300$ \\
\hline COD & $\mathrm{mg} / \mathrm{L}\left(\mathrm{O}_{2}\right)$ & 46.0 & 32.0 & 50.1 & 47.2 & $\leq 35$ \\
\hline $\mathrm{TS}$ & $\mathrm{mg} / \mathrm{L}$ & 0.29 & 0.14 & 0.32 & 0.27 & $\leq 0.5$ \\
\hline Toxicity & $\begin{array}{l}\text { \% } \\
\text { immobiliza } \\
\text { tion }\end{array}$ & Non toxic & Non toxic & $\begin{array}{l}\text { Non } \\
\text { toxic }\end{array}$ & $\begin{array}{l}\text { Non } \\
\text { toxic }\end{array}$ & Non toxic \\
\hline SDI & & - & - & - & - & 5 \\
\hline
\end{tabular}

The effectiveness of the Ultrasonic treatment in the removal (\%) of the most critical parameters has been evaluated (Figure 2). 


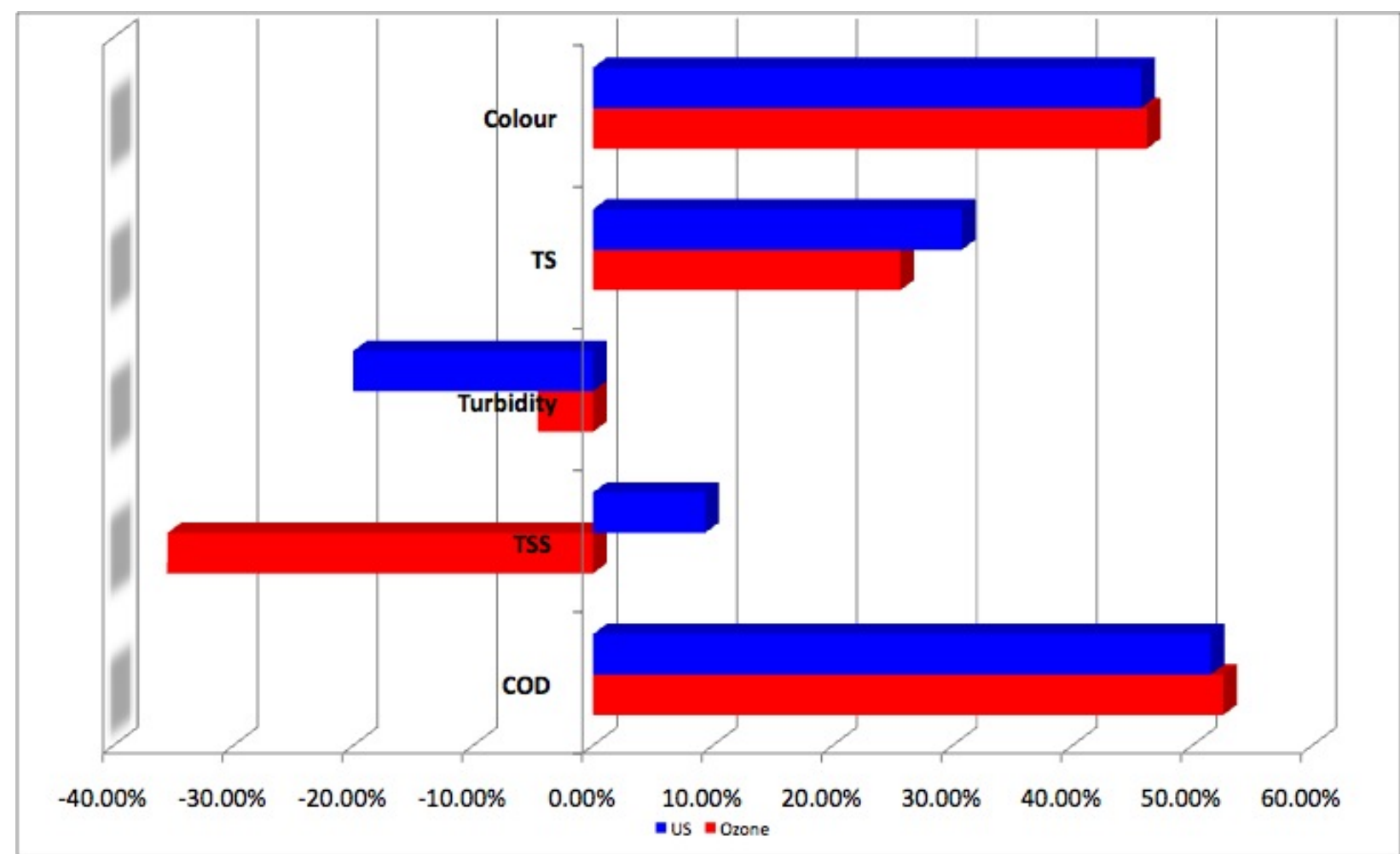

Figure 2 - Comparison of the performance of primary ozonation and Ultrasonic treatment

The data collected in the figure showed that almost the same performances can be ensured by the US in comparison with ozone. According to that, the US seems to be a promising alternative to the primary ozonation.

\subsection{Test with UF pilot provided by INGE}

The optimal process conditions for the Ultrafiltration membrane UF100 are listed in table 4.

Table 4 - Inge pilot plant operating conditions for UF100

\begin{tabular}{|l|l|}
\hline Working parameter & Value \\
\hline Flux & $60 \mathrm{l} / \mathrm{hm}^{2}$ \\
\hline Production time & $15 \mathrm{~min}$ \\
\hline Backwash time & $40 \mathrm{sec}$ \\
\hline Backwash flow & $60 \mathrm{l} / \mathrm{h}$ (filtrate water) \\
\hline Chemical Enhanced Backwash (CEB) & 1 every 4 production cycles by using: \\
& $30 \mathrm{~min} .1 \mathrm{~g} / 1 \mathrm{NaOH}^{-}$ \\
& $15 \mathrm{~min} .2 \mathrm{~g} / 1 \mathrm{H}_{2} \mathrm{SO}_{4}$ \\
\hline Coagulation dose & $6 \mathrm{mg} / \mathrm{L}$ polyaluminiumhydroxidchlorisulfat \\
\hline Membrane Cleaning in Place (CIP) & none \\
\hline
\end{tabular}

In fact, by applying these conditions a quite constant behaviour in the flux of the filtration systems can be ensured over a period of 6 months, as shown in the figure 3 . 
Linnaeus ECO-TECH '10

Kalmar, Sweden, November 22-24, 2010

Purifast UF100; 20.11.2009 - 25.05.2010

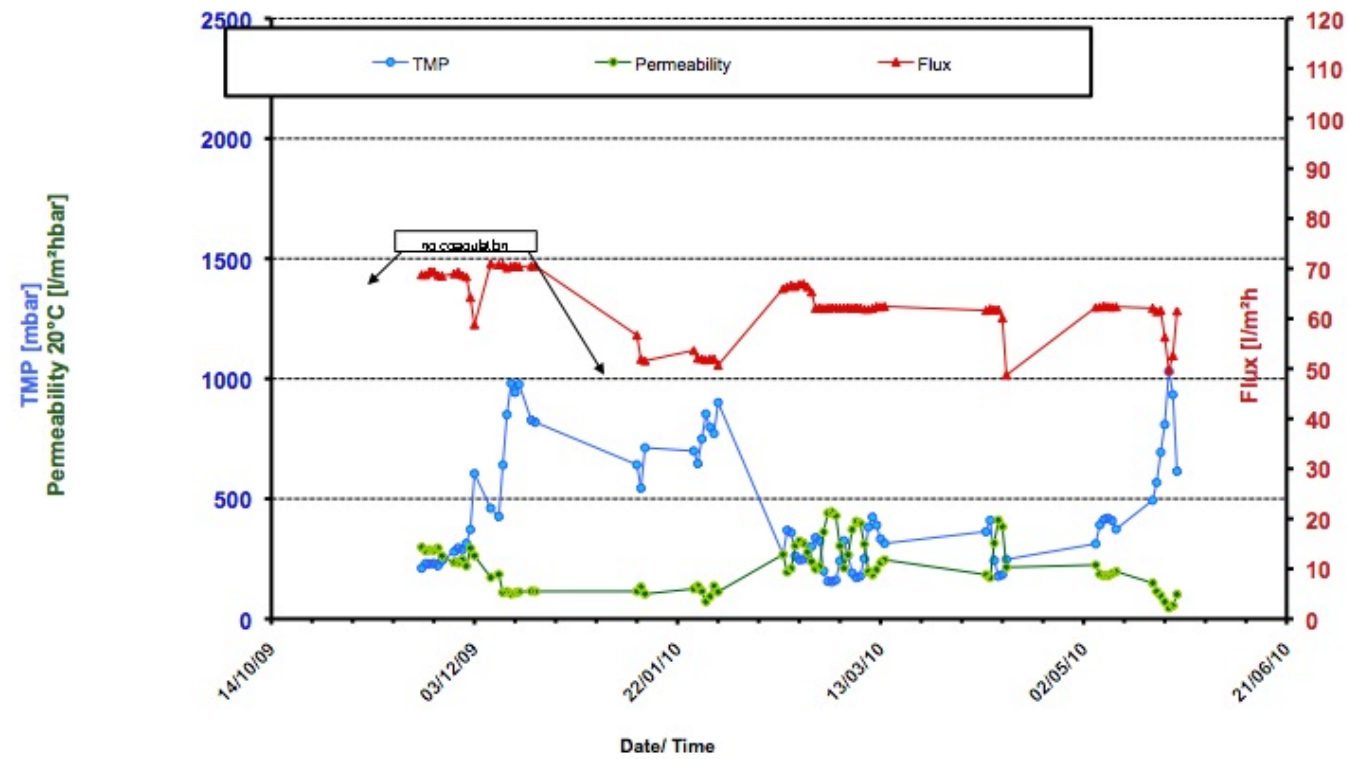

Figure 3 - Hydraulic performances of UF100 system

The tests showed that the following hydraulic performances at a constant value of flux (50 $\mathrm{L} / \mathrm{m} 2 \mathrm{~h}$ ) can be ensured in this configuration:

TMP (average value): 265 mbar

Lp (average value): 245 1/nm² bar

By applying this conditions to the effluent coming from the US treatment the following parameters have been achieved (Table5). 
Table 5 - Results of the chemical and physical characterisation of treated wastewater with the combined process

\begin{tabular}{|c|c|c|c|c|c|}
\hline \multirow[b]{2}{*}{ Parameter } & \multirow[b]{2}{*}{ Unit } & \multicolumn{3}{|c|}{ US (non ozonised water) + UF (INGE) } & \multirow{2}{*}{$\begin{array}{c}\text { PURIFAST } \\
\text { Target }\end{array}$} \\
\hline & & Low value & $\begin{array}{c}\text { Max } \\
\text { Value }\end{array}$ & Average & \\
\hline $\mathrm{pH}$ & - & 7.0 & 7.3 & $7.1^{*}$ & $6-8$ \\
\hline Conductivity & $\mu \mathrm{S} / \mathrm{cm}$ & 1489 & 2260 & 1847 & $\leq 3000$ \\
\hline Turbidity & NTU & 0.5 & 0.8 & 0.66 & $\leq 5$ \\
\hline TSS & $\mathrm{mg} / \mathrm{L}$ & - & - & $\leq 5$ & $\leq 5$ \\
\hline Hardness & $\mathrm{mg} / \mathrm{L}$ & 33.6 & 43.2 & 37.1 & $\leq 50$ \\
\hline Colour & $\mathrm{A} / \mathrm{nm}$ & 0.29 & 0.80 & 0.56 & $\leq 2$ \\
\hline $\mathrm{SiO}_{2}$ & $\mathrm{mg} / \mathrm{L}$ & 6.78 & 9.10 & 7.45 & $\leq 25$ \\
\hline Chlorides & $\mathrm{mg} / \mathrm{L}$ & 288.0 & 307.00 & 304.2 & $\leq 500$ \\
\hline Sulphates & $\mathrm{mg} / \mathrm{L}$ & 134 & 228 & 210.6 & $\leq 300$ \\
\hline COD & $\mathrm{mg} / \mathrm{L}\left(\mathrm{O}_{2}\right)$ & 31.0 & 49.0 & 37.6 & $\leq 35$ \\
\hline TS & $\mathrm{mg} / \mathrm{L}$ & 0.12 & 0.33 & 0.21 & $\leq 0.5$ \\
\hline Toxicity & $\begin{array}{l}\text { \% } \\
\text { immobilization }\end{array}$ & Non toxic & Non toxic & Non toxic & Non toxic \\
\hline SDI & & - & - & $4-6$ & 5 \\
\hline
\end{tabular}

With the exception of the colour, the UF system is able to significantly reduce the solid charge of the effluent. In order to overcome this problem two approach can be investigated; a more suitable dosing of hydrogen peroxide (its overdosing seems to be responsible for this data) can be made or a new design of the purification treatment layout has to be done. According to the project results the following treatment steps can be proposed. 


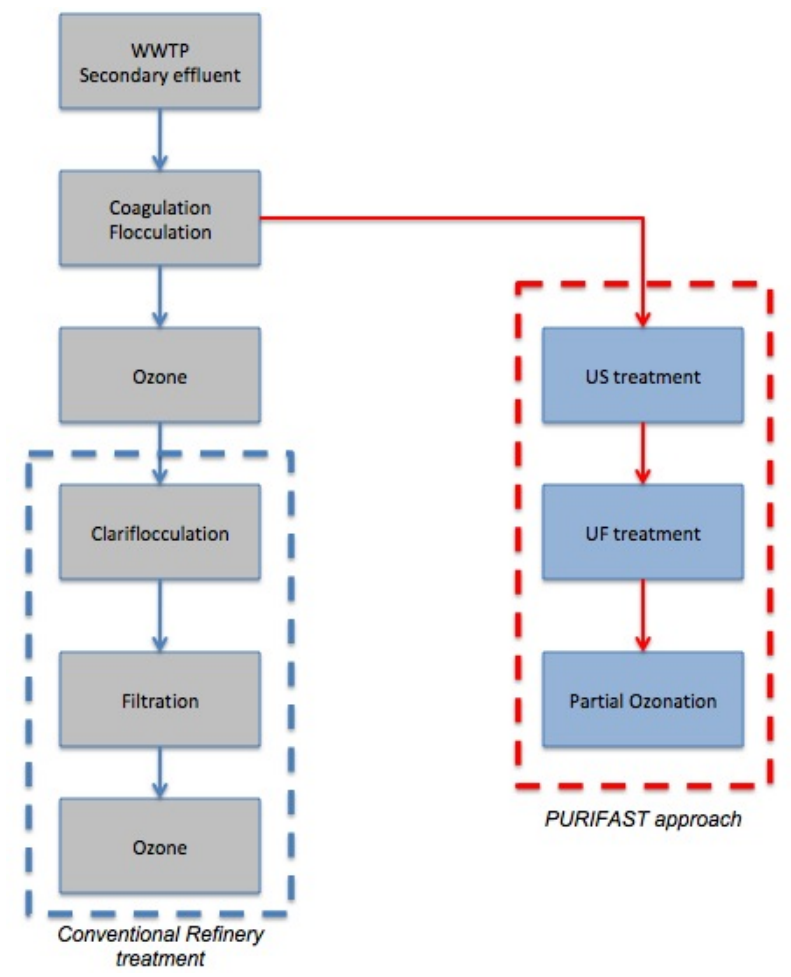

Figure 4 - Layout of the PURIFAST approch at GIDA compared with the conventional one

\section{CONCLUSIONS}

The activities carried out within the PURIFAST project seem to confirm that the combination of Ultrasonic treatment and Ultrafiltration is a promising approach for the purification of textile and mixed wastewater. In fact, the cavitation phenomena related with the bubble collapses in the US equipment is able to generated hydroxyl radical and to catalyse the dissociation of hydrogen peroxide enabling to degrade organic pollutants dissolved in the effluents. Furthermore, the usage of a user-friendly technology such as Ultrasound should represent a benefit according to the low investment costs required for the purchasing of the apparatus and to the lower usage of toxic compounds (ozone is an high toxic gas and the usage of inappropriate amount of ozone for wastewater treatment can generate toxic intermediates as reported in literature [4]).

Moreover, the combination of an AOP with UF system allow to reduce the amount of solid particles and pollutants responsible for a significant amount of the COD load. The problem related with the overdosing of hydrogen peroxide could be easily solved by implementing a dosing systems or by using a partial ozonation.

A preliminary economical evaluation for the proposed approach has been done: a overall cost of around $1.39 € / \mathrm{m}^{3}$ for the Combination US and INGE UF system with sonochemical treatment carried out for $4 \mathrm{~h}$ is expected. This is quite high but it is promising according to the cost of fresh water in Europe (in countries such as Sweden, Germany is around $2 € / \mathrm{m}^{3}$ ) considering that a reduction up to $70 \%$ is expected at full scale. 


\section{REFERENCES}

16. M. Marcucci, G. Nosenzo, G. Capannelli, I. Ciabatti, D. Corrieri and G. Ciardelli, 2001. Treatment and reuse of textile effluents based on new ultrafiltration and other membrane technologies. Desalination. 138, 75-82.

17. D. Mattioli, F. Malpei, G. Bordone, A. Rozzi, 2002. Water minimisation and reuse in the textile industry. Water Recycling and Resource Recovery in Industry: Analysis, Technologies and Implementation - IWA Publishing.

18. E. Companyamp; T. Asano, F. L. Burton, H. L. Leverenz, R. Tsuchihashi, G. Tchobanoglous, 2007, Water Reuse, Mc Graw Hill.

19. E. C. Werta, F. L. Rosario-Ortiza, D. D. Druryb, Shane, A. Snydera., 2007. Formation of oxidation byproducts from ozonation of wastewater. Water research. 41, 1481-1490. 